\title{
Experimental Study on Mechanical Properties of Geopolymer Concrete Using GGBS
}

\author{
Asha Philip ${ }^{1}$, Ashok Mathew ${ }^{2}$ \\ ${ }^{1}$ PG Scholar, Structural Engineering, SBCE, Kerala, India \\ ${ }^{2}$ Assistant Professor, Department of Civil Engineering, SBCE, Kerala, India
}

\begin{abstract}
The aim of this investigation is to develop an environmental friendly construction material using geopolymer concrete. The geopolymer technology is proposed by Davidovits and gives considerable promise for application in concrete industry as an alternative binder to the Portland cement. In terms of reducing the global warming, the geopolymer technology could reduce the $\mathrm{CO}_{2}$ emission in to the atmosphere, caused by cement industries about 80\%. In this technology, the source material that is rich in silicon (Si) and Aluminum (Al) is reacted with a highly alkaline solution through the process of geo polymerization to produce the binding material. The project aim is to use GGBS (Ground Granulated Blast Furnace Slag) in place of OPC and compare its properties with the normal concrete. In the present investigation, it is proposed to study the mechanical properties viz.Compressive strength, Split tensile strength, Flexural strength test on the concrete specimens. Hopefully one day in the near future geopolymer concrete will replace ordinary Portland cement as the most abundant man-made material on earth.
\end{abstract}

Keywords: Geopolymer concrete, GGBS, Alkaline solution, Mechanical properties.

\section{Introduction}

Concrete is one of the most widely used construction materials; main ingredient of concrete is cement. The demand for concrete as a construction material is on the increase. It is estimated that the production of cement increased from about from 1.5 billion tons in 1995 to 3.2 billion tons in 2016 . However, the utilization of cement causes pollution to the environment and reduction of raw material (limestone). The production of Portland cement worldwide is increasing 9\% annually. The current contribution of greenhouse gas emission from Portland cement production is about 1.5 billion tons annually or about $7 \%$ of the total greenhouse gas emissions to the earth's atmosphere. In India about 36 billion metric tons of $\mathrm{CO} 2$ is emitted in the year of 2015. The cement industry contributes about $5 \%$ of total global carbon dioxide emissions. The cement is manufactured by using the raw materials such as lime stone, clay and other minerals. Quarrying of these raw materials is also causes environmental degradation. To produce 1 ton of cement, about 1.6 tons of raw materials are required and the time taken to form the lime stone is much longer than the rate at which humans use it. On the other side the demand of concrete is increasing day by day for its ease of preparing and fabricating in all sorts of convenient shapes. So to overcome this problem, the concrete to be used should be environmental friendly. To produce environmental friendly concrete, we have to replace the cement with the industrial by products such as flyash, GGBS etc. In this respect, the new technology geopolymer concrete is a promising technique.

The term geopolymer was first coined by Davidovits in 1978 to represent a broad range of materials characterized by chains or networks of inorganic molecules. Geopolymer are chains or networks of mineral molecules linked with covalent bonds. Geopolymer is produced by a polymeric reaction of alkaline liquid with source material of geological origin or by product material such as GGBS. Geopolymers have the chemical composition similar to zeolites but they can be formed an amorphous structure. For the binding of materials the silica and alumina present in the source material are induced by alkaline activators. The most common alkaline liquid used in the geopolymerization is the combination of sodium hydroxide/ potassium hydroxide and sodium silicate/ potassium silicate. This combination increases the rate of reaction. Among 15 alumino-silicate minerals, all the Al-Si minerals are more soluble in $\mathrm{NaOH}$ solution than in $\mathrm{KOH}$ solution. GGBS is a waste material generated in iron or slag industries have significant impact on strength and durability of geopolymer concrete.

\section{Objective of the Work}

The project aim is to produce geopolymer concrete using GGBS and compare its mechanical properties with the normal concrete.

\section{Materials}

\subsection{Ground Granulated Blast Furnace Slab (GGBS)}

The GGBS is obtained by a byproduct of iron and steel in blast furnace to produce a glassy, granulated product that is then dried and ground in to a fine powder. The properties of GGBS are given in Table 1 .

Table 1: Properties of GGBS

\begin{tabular}{|c|c|}
\hline Particulars & Test results \\
\hline Specific gravity & 2.9 \\
\hline Fineness $\left(\mathrm{M}^{2} / \mathrm{Kg}\right)$ & 385 \\
\hline Initial setting time (min) & 170 \\
\hline Magnesia content (\%) & 7.57 \\
\hline Sulphide sulphur (\%) & 0.51 \\
\hline Sulphite content (\%) & 0.42 \\
\hline Loss on ignition (\%) & 0.25 \\
\hline
\end{tabular}




\section{International Journal of Science and Research (IJSR) \\ ISSN (Online): 2319-7064}

Index Copernicus Value (2013): 6.14 | Impact Factor (2015): 6.391

\subsection{Aggregate}

Coarse aggregates of size $20 \mathrm{~mm}$ and fine aggregate used was locally supplied and conformed to grading zone I as per IS: 383:1970 and they have the properties as given in Table 2 .

Table 2: Properties of aggregates

\begin{tabular}{|c|c|c|}
\hline Properties & Coarse aggregate & Fine aggregate \\
\hline Specific gravity & 2.77 & 2.61 \\
\hline Fineness modulus & 7.06 & 3.59 \\
\hline Bulk density & $1.59 \mathrm{~g} / \mathrm{cc}$ & $1.2 \mathrm{~g} / \mathrm{cc}$ \\
\hline
\end{tabular}

\subsection{Alkaline solutions}

The solutions of sodium hydroxide and sodium silicate are used as alkaline solutions in the present study. Commercial grade sodium hydroxide in flakes form (97\%-100\% purity) and sodium silicate solution having $7.5 \%-8.5 \%$ of $\mathrm{Na} 2 \mathrm{O}$ and $25 \%-28 \%$ and water of $67.5 \%-63.5 \%$ are used in the present study).

\subsection{Cement}

43 grade OPC conforming to IS 8112-1989 was used for the experimental programme. The test results on cement are tabulated in Table 3. The results conform to IS 12269-1967 recommendations.

Table 3: Properties of cement

\begin{tabular}{|c|c|}
\hline Properties & Test results \\
\hline Standard consistency & $33 \%$ \\
\hline Initial setting time & $60 \mathrm{~min}$ \\
\hline Final setting time & $6 \mathrm{hour}$ \\
\hline Fineness & $1 \%$ \\
\hline Specific gravity & 3.2 \\
\hline
\end{tabular}

\subsection{Superplasticizer}

In order to achieve the desired workability, a naphthalene based superplasticizer was used as the water reducer. In this present investigation, superplasticizer namely CERAPLAST SP 300 has been used for obtaining workable concrete at low w/c ratio. It is based upon NSF condensates used for this study. The mechanism consists of very large molecules (colloidal size) which dissolve in water to produce ions with high negative charge (anions).

\section{Methodology}

\subsection{Preparation of Alkaline Solutions}

In this research work the strengths of geopolymer concrete is examined for the mixes of 10 molarity of sodium hydroxide. The molecular weight of sodium hydroxide is 40 . To prepare 10 molarity of solution $400 \mathrm{~g}$ of sodium hydroxide flakes are weighed and they can be dissolved in distilled water to form 1 litre solution. Volumetric flask of 1 litre capacity is taken,sodium hydroxide flakes are added slowly to distilled water to prepare 1litre solution. The allkali activator solution has to be prepared 24 hours advance before use.

\subsection{Mix Design}

In the present study M25 grade concrete were used. Similar grade of geopolymer concrete were designed and optimized by trial and error method. The sodium silicate to sodium hydroxide ratio was fixed as 2.5 and the concentration of $\mathrm{NaOH}$ was taken as $10 \mathrm{M}$. Optimized and proper mix design for conventional concrete and geopolymer concrete is given in Table 4.

Table 4: Final mixes

\begin{tabular}{|c|c|c|}
\hline Materials & $\begin{array}{c}\text { Normal } \\
\text { concrete }\left(\mathrm{kg} / \mathrm{m}^{3}\right)\end{array}$ & $\begin{array}{c}\text { Geopolymer } \\
\text { concrete }\left(\mathrm{kg} / \mathrm{m}^{3}\right)\end{array}$ \\
\hline GGBS & $\mathrm{Nil}$ & 419.7 \\
\hline Cement & 526 & Nil \\
\hline Fine aggregate & 526 & 608.1 \\
\hline Coarse aggregate & 1053 & 1018 \\
\hline $\mathrm{NaOH}$ solution & $\mathrm{Nil}$ & $68.5(10 \mathrm{M})$ \\
\hline $\mathrm{Na}_{2} \mathrm{SiO}$ & $\mathrm{Nil}$ & 171.1 \\
\hline $\mathrm{Water}$ & 237 & 44.2 \\
\hline Superplasticizer & $\mathrm{Nil}$ & 8.3 \\
\hline
\end{tabular}

\subsection{Casting and Curing}

Firstly, the fine aggregate, coarse aggregate and GGBS were mixed in dry condition for 3-4minutes and then the alkaline solution which is a combination of sodium hydroxide solution and sodium silicate solution with superplasticizer was added to the dry mix. The superplasticizer is taken as $2 \%$ of the cementious material. The mixing is done for about 6- 8 mins for proper bonding of all the materials. After the mixing is done, specimens are casted by giving proper compaction in three layers. For the curing, the geopolymer specimens are demoulded after 1 day of casting and they are placed in room temperature (Ambient curing) and the normal concrete specimens are cured under water.

\subsection{Testing of Specimens}

The specimens are tested at the age of 7 and 28 days of curing For each mix proportion three numbers of cubes were tested at the age of 7 days and 28 days. For each mix proportion three numbers of cylinders were tested at age of 7 days and 28 days. For each mix proportion three numbers of prisms tested at the age of 7 days and 28 days.

Table 5: Details of specimen

\begin{tabular}{|c|c|c|}
\hline Name of Test & Size of specimen $(\mathrm{mm})$ & $\begin{array}{c}\text { Number of } \\
\text { specimen }\end{array}$ \\
\hline Compressive Test & Cube(150x150x150) & 12 \\
\hline Split Tensile Test & Cylinder(150Dia\&300Ht) & 12 \\
\hline Flexural Test & Prism(100x100x50) & 12 \\
\hline
\end{tabular}

\section{Observations and Results}

\subsection{Compressive Strength Test}

The variation of compressive strength at the age of 7 th and 28th days for both normal concrete and geopolymer concrete specimens were given below in Figure: 1. From the test results, it was observed that compressive strength value at 7 days curing period is higher than that of the conventional concrete. 


\section{International Journal of Science and Research (IJSR) \\ ISSN (Online): 2319-7064}

Index Copernicus Value (2013): 6.14 $\mid$ Impact Factor (2015): 6.391

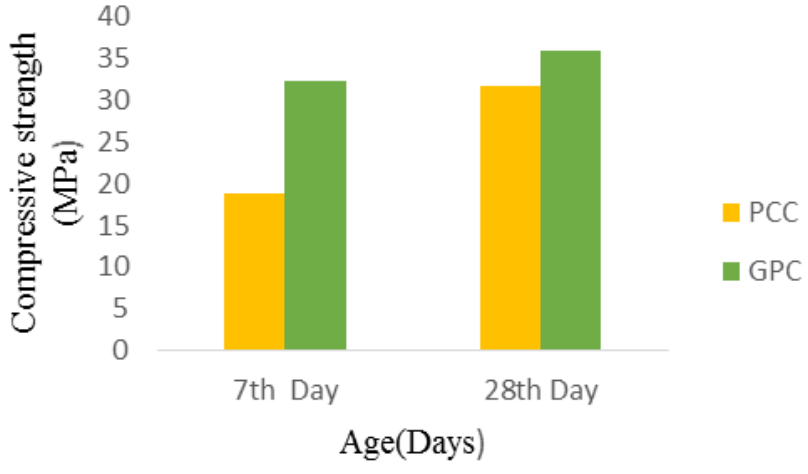

Fiugre: 1 Compressive strength at the age of 7 days and 28 days

\subsection{Split Tensile Strength}

The results of split tensile strength of concrete at the age of 7 days and 28 days are presented in Figure: 2. From the test results, it was observed that geopolymer concrete specimens have higher split tensile strength than normal concrete specimens.

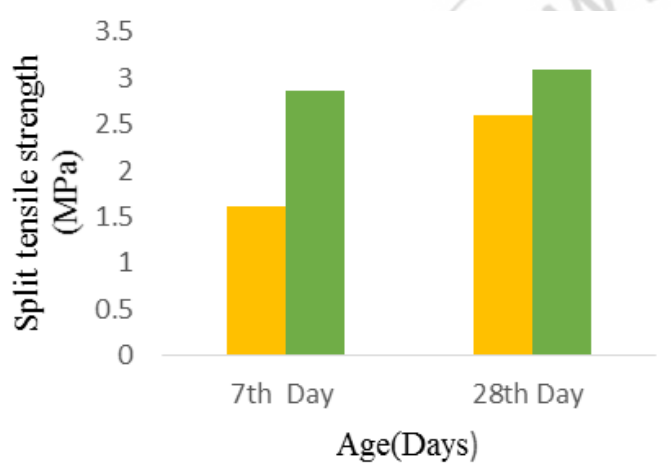

Figure: 2 Split Tensile strength at the age of 7 days and 28

\subsection{Flexural Strength} days

The results of flexural strength of concrete at the age of 7 days and 28 days are presented in Figure: 3.From the test results, it was observed that flexural strength is higher for geopolymer concrete specimens

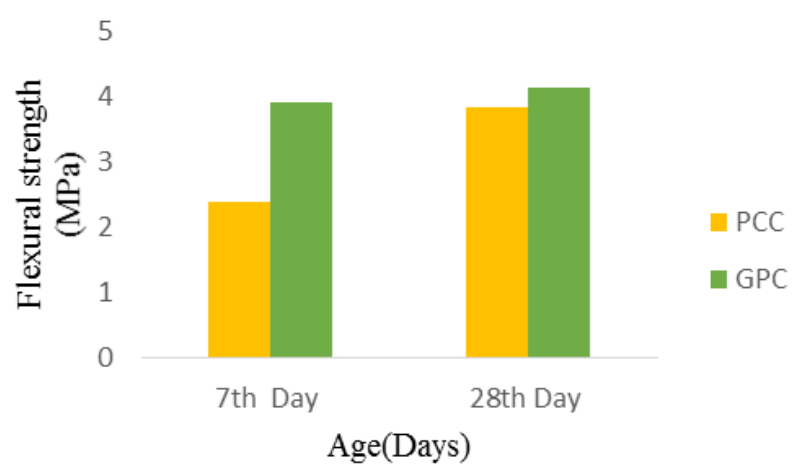

Figure: 3 Flexural strength at the age of 7 days and 28 days.

\section{Discussions}

Due to the high early strength Geopolymer Concrete shall be effectively used in the precast industries, so that huge production is possible in short duration and the breakage during transportation shall also be minimized. The Geopolymer Concrete shall be effectively used for the beam column junction of a reinforced concrete structure. Geopolymer Concrete shall also be used in the Infrastructure works. Apart from less energy intensiveness, the GCs utilize the industrial wastes for producing the binding system in concrete. There are both environmental and economical benefits of using GGBS.

The government can make necessary steps to extract sodium hydroxide and sodium silicate solution from the waste materials of chemical industries, so that the cost of alkaline solutions required for the geopolymer concrete shall be reduced.

\section{Conclusions}

Based on the results obtained in the experimental investigation, the following conclusions are found.

- Geopolymer Concrete made up of GGBS and alkaline solution Provides, a new era in the construction industry.

- GGBS makes significant impact on the strength of geopolymer concrete.

- The mechanical properties are higher for geopolymer concrete and rate of gain of geopolymer concrete is very fast at 7 days curing period. Hence give faster construction of products.

- GGBS based geopolymer concrete has excellent compressive strength and is suitable for structural applications.

\section{Scope for Future Study}

- Study on the addition of various fibres in geopolymer concrete and their effect on enhancement of strengths.

- Different structural elements like Geopolymer Concrete Beam, Reinforced Geopolymer Concrete Beam, Reinforced Geopolymer Concrete Columns, Reinforced Beam Column joints shall be cast for the different concentrations of sodium hydroxide solution and curing conditions.

\section{References}

[1] C.A. Hendriks1, "Emission Reduction of Greenhouse Gases from the Cement Industry"Greenhouse gas control technologies conferencepaper.

[2] Ernst Worerell. Lynn Price, et al. "CO2 emission from the global cement industry", Annual reviewof energy and the environment. Vol 26: p-303-329.

[3] D.B.Rajiwala,H.S.Pat 7il(2011)“Geopolymer Concrete : A Concrete Of Next Decade" Journal of Engineering Studies and Research (JERS) Vol. II Issue 1

[4] IS 10262-2009 - "Concrete mix proportion guidelines"Bureau of Indian standards - New Delhi 
[5] IS 456-2000 - "Plain and Reinforced concrete code of practice"- Bureau of Indian standards - New Delhi

[6] P.GanapatiNaidu,A.S.V.Satayanarayana(2012)“:A

Study On Strength Properties Of Geopolymer Concrete With Addition Of G.G.B.S” International Journal of Engineering Research and Development Volume 2, Issue 4, PP. 19-28.

[7] V.Supraja,M.Kanta Rao(2012)-Experimental Study On Geopolymer Concrete Incorporating Ggbs-Issn:22779477, Volume 2,Isssue 2.

[8] Raijiwala D.B.1 Patil H. S.2 (2011) -Geopolymer Concrete: A Concrete of Next Decade, E-Issn 09767916.

\section{Author Profile}

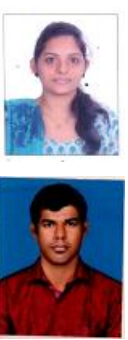

Asha Philip is MTech student,Structural Engineering, Sree Buddha College of Engineering, Anupama, Mannady P O, Adoor, Pathanamthitta-691530,Kerala, India

Ashok Mathew is Assistant Professor, Department of Civil Engineering, Sree Buddha College of Engineering, Asokam, Ambipoika (P.O), Kundara, Kollam-691501, Kerala, India 